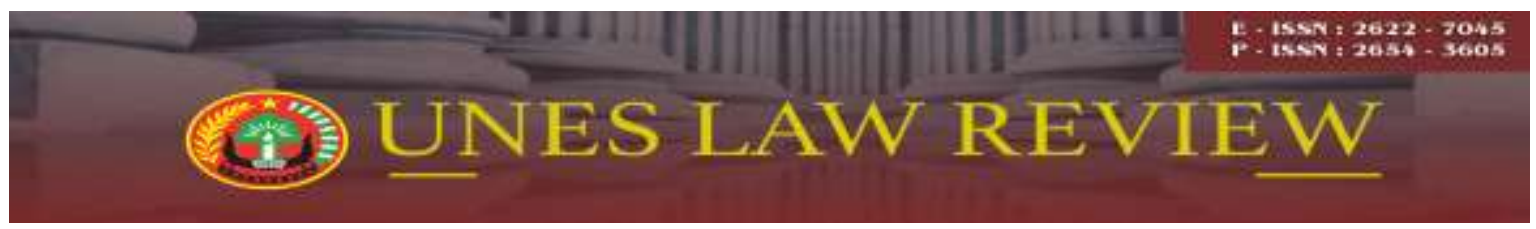

Email: uneslawreview@gmail.com

Online: http://review-unes.com/index.php/law

Volume 2, Issue 2, Desember 2019

\title{
PEMBATASAN JUMLAH AKTA NOTARIS BERDASARKAN KEWAJARAN DI KOTA PADANG
}

\author{
1) Rionald Harris, ${ }^{2)}$ Zainul Daulay, ${ }^{3)}$ Beatrix Benni \\ Pasca Serjana Hukum, Universitas Andalas, Padang, Indonesia \\ E-mail : rionaldharris123@gmail.com
}

\begin{abstract}
The Honorary Board of the Indonesian Notary Association as the organ of the Indonesian Notary Association issues a regulation regarding the Fairness of the Deed Making Certificate per Notary for 20 deeds per day. Based on pre-research, there are still many notaries who do not know about the regulation in Padang. Why a Notary is prohibited from making a deed exceeding the fairness limit, what factors becomes the reasons for a Notary in Padang to make a deed exceeding the fairness limit and the legal consequences of a deed exceeding the fairness limit will be the topic of discussion in this paper. The research method used is a type of empirical juridical research and the nature of analytical descriptive research; data collection is done by using data in the form of primary material as primary data, supported by secondary and tertiary materials. The data obtained are then processed, analyzed, and interpreted qualitatively. Compliance is a virtue that moves people to act rationally in using what is fair, it is important for Notary to be given reasonable limits on the deeds that they can make per day so that the Notary does not exceed their physical ability to make daily deeds. The Law of Notary Position does not limit the number of deeds that can be made by the Notary per day, so that there are still notaries who make the deed exceed the reasonable limits set especially Fiduciary deed in Padang. Notary Deed that exceeds the fairness limit determined by the Honorary Board of Notary will not be degraded to privately-made deed, provided that what is done by Notary in making the deed is in accordance with the Law of Notary Position. The reasonable limit of making a daily deed issued by the Indonesian Notary Association Honorary Board should be included in the Minister Law or Regulation because basically the DKP.INI 1 regulation in 2017 only binds members of the association. Had the notary been expelled from the association, it would not have had any effect on his position.
\end{abstract}

Kata Kunci: Pembatasan, Akta Notaris, Batas Kewajaran Pembuatan Akta Perhari

\section{PENDAHULUAN}

Ikatan Notaris Indonesia merupakan perkumpulan yang tujuannya sebagai ajang pertemuan dan bersilaturahmi antara para Notaris yang menjadi anggotanya (perkumpulan satu-satunya bagi notaris Indonesia) dan berdasarkan Broederschap van CandidaatNotarissen in Nederlanden zijne Kolonien' dan Broederschap der Notarissen di Negeri 
Belanda, Ikatan Notaris Indonesia diakui sebagai badan hukum (rechtspersoon) dengan Gouvernements Besluit (Penetapan Pemerintah) tanggal 5 September 1908 No. 9. DeNederlandsch Indische Notarieele Vereeniging-Batavia (sekarang Jakarta) Tanggal 1 Juli 1908. Pada masa itu Pengurus notaris berkebangsaan Belanda yaitu LM.Van Sluijters, E.H. Carpentir Alting, H.G. Denis, H.W. Roebey, W. an Der Meer dan Anggota Perkumpulan terdiri dari Notaris dan Calon Notaris Indonesia (pada waktu itu Nederlandsch Indie).

Berdasarkan uraian diatas, maka Notaris Indonesia berkumpul dalam satu organisasi yaitu Ikatan Notaris Indonesia (selanjutnya disebut I.N.I) yang merupakan wadah perkumpulan/organisasi bagi Notaris, yang didirikan pada tanggal 1 Juli 1908, diakui sebagai badan hukum (Rechtpersoon) berdasarkan Petetapan Pemerintah (Gouvernements Besluit) tanggal 5 September 1908 Nomor 9, yang mana merupakan satusatunya wadah pemersatu bagi semua dan setiap orang yang memangku dan menjalankan tugas jabatannya sebagai Pejabat Umum. Sebagaimana hal itu telah diakui dan mendapat pengesahan dari Pemerintah berdasarkan Anggaran Dasar Perkumpulan Notaris yang telah mendapatkan Penetapan Menteri Kehakiman tertanggal 4 Desember 1958 Nomor J.A.5/117/6 dan diumumkan dalam Berita Negara Republik Indonesia tanggal 6 Maret 1959 Nomor 19, Tambahan Berita Negara Republik Indonesia Nomor 6, dan perubahan anggaran dasar yang terakhir telah mendapat persetujuan dari Menteri Hukum dan Hak Asasi Manusia Republik Indonesia berdasarkan Surat Keputusan 12 Januari 2009 Nomor AHU- 03.AH.01.07.Tahun 2009. Oleh karena itu sebagai dan merupakan Organisasi Notaris sebagaimana yang dimaksud dalam Undang-Undang Nomor 30 tahun 2004 tentang Jabatan Notaris yang diundangkan berdasarkan Lembaran Negara Republik Indonesia Tahun 2004 Nomor 117, Tambahan Lembaran Negara Republik Indonesia Nomor 4432 serta mulai berlaku pada tanggal 6 Oktober 2004, sebagaimana telah diubah dengan Undang-Undang Nomor 2 Tahun 2014 tentang Perubahan Atas Undang-Undang Nomor 30 Tahun 2004 tentang Jabatan Notaris yang telah diundangkan dalam Lembaran Negara Tahun 2014 Nomor 3, Tambahan Lembaran Negara Nomor 5491.

Pentingnya agar tidak terjadi pelanggaran dalam menjalankan Jabatan Notaris, terutama dalam jumlah akta yang dibuatnya, dalam satu hari kerja melebihi 20 akta, yang memungkinkan terjadinya pelangggaran terhadap akta tersebut, sehingga diperlukan Peraturan yang mengaturnya. Salah satu yang telah disepakati dalam Kongres Ikatan 
Notaris Indonesia adalah mengenai batas kewajaran pembuatan akta perhari. Hal ini tercantum dalam Pasal 4 angka 16 Perubahan Kode Etik Notaris Tahun 2015, yang menentukan "Notaris maupun orang lain (selama yang bersangkutan menjalankan jabatan Notaris) dilarang : "Membuat akta melebihi batas kewajaran yang batas jumlahnya ditentukan oleh Dewan Kehormatan;" Dengan ditetapkannya ketentuan tersebut, maka sangat jelas bahwa Batasan kewajaran pembuatan akta adalah norma yang masuk dalam Kode Etik Notaris, yang wajib dipatuhi oleh semua Notaris atau semua orang yang menjalankan Jabatan Notaris.

Hal ini dilakukan supaya Jabatan Notaris dan masyarakat yang menggunakan jasa Notaris terlindungi terkait dengan kepastian Hukum dari akta yang dibuat oleh Notaris. Pada tanggal 28 Februari 2017, Dewan Kehormatan Pusat Ikatan Notaris Indonesia mengeluarkan Peraturan Dewan Kehormatan Pusat Nomor 1 Tahun 2017 Tentang Batas Kewajaran Jumlah Pembuatan Akta Perhari. (selanjutnya disebut Per.DKP.INI 1/2017), peraturan yang ditentukan oleh Dewan Kehormatan Pusat bahwa kewajaran dalam pembuatan akta dalam sehari adalah 20 (dua puluh) akta, yang mana peraturan ini menimbulkan pro dan kontra dikalangan notaris itu sendiri.

Adapun maksud dibuatnya ketetapan pembatasan jumlah akta per hari memang tidak ada dijelaskan didalam Peraturan Dewan Kehormatan Pusat Ikatan Notaris Indonesia Nomor 1 Tahun 2017 akan tetapi mengingat Peraturan Dewan Kehormatan Pusat Ikatan Notaris Indonesia Nomor 1 Tahun 2017 lahir dari ketentuan Kode Etik Notaris yang menyangkut kaidah moral dan Jabatan Notaris merupakan jabatan dengan menjunjung tinggi nilai profesionalitas dan berwibawa maka sudah sewajarnya seorang Notaris dalam bertindak harus menjunjung tinggi sikap profesionalitas kerja dalam melayani masyarakat khususnya pada pembuatan akta dalam jumlah batas kewajaran yakni 20 (dua puluh) akta per hari.

Disamping itu apabila memperhatikan jam kerja Notaris yang lazim digunakan oleh Notaris maka penggunaan waktu tersebut adalah antara pukul 8 (delapan) pagi sampai dengan pukul 17 (tujuh belas), dan jam istirahat pada pukul 12 (dua belas) sampai dengan pukul 13 (tiga belas), maka jumlah jam yang dipergunakan adalah 8 (delapan) jam sehari, artinya apabila tanpa jeda keluar masuk atau berganti orang yang membuat akta, jumlah waktu yang dibutuhkan dengan jumlah pembatasan akta 20 (dua puluh) akta satu hari 
adalah 8 (delapan) dikali 60 (enam puluh) menit dan dibagi 20 (dua puluh) akta maka didapat hasil 24 (dua puluh empat) menit waktu yang dibutuhkan. Lazimnya waktu 24 menit dalam membuat 1 (satu) akta sudah termasuk didalamnya pembacaan dan penandatangan akta, yang apabila dikalkulasikan adalah 10 (sepuluh) menit, dengan demikian pembuatan akta memakan waktu 14 (empat belas) menit. Namun pada praktiknya 1 (satu) akta dari mulai konseling, pembuatan dan pembacaan hingga penandatanganan aktanya bisa memakan waktu hingga 30 (tiga puluh) menit paling cepat. Maka dari itu Per.DKP INI 1/2017 ini pada dasarnya menjaga para anggotanya agar membuat akta Notaris sesuai dengan Undang-Undang Jabatan Notaris.

Maka, berdasarkan uraian diatas penulis tertarik untuk melakukan penelitian tesis dengan judul: "Pembatasan Jumlah Akta Notaris Berdasarkan Batas Kewajaran Pembuatan Akta Perhari di Kota Padang”.

\section{METODE PENELITIAN}

Metode penelitian yang telah digunakan adalah penelitian hukum empiris. Penelitian hukum empiris adalah penelitian hukum sosiologis yang dapat disbeut juga dengan penelitian lapangan.

Metode pendekatan masalah yang dipakai dalam penelitian ini adalah pendekatan yuridis empiris, yaitu permasalahan yang dikaji atas materi hukum atau peraturanperaturan yang ada dikaitkan dengan materi penelitian kepustakaan untuk memperoleh data sekunder dan penelitian lapangan untuk memperoleh data primer (Ade Saptomo, 2007:33). Tipe penelitian dalam penulisan tesis ini bersifat penelitian deskriptif analisis yaitu menganalisa data yang dipergunakan baik data primer dan data sekunder, meliputi isi dan struktur hukum positif yang akan ditentukan penulis untuk menentukan isi atau makna aturan hukum yang dijadikan rujukan dalam menyelesaikan permasalahan hukum yang menjadi objek kajian (Zainuddin Ali, 2011:31).

Teknik pengumpulan data primer dan sekunder yang digunakan adalah: Wawancara, Teknik dokumentasi adalah Teknik pengumpulan data yang berwujud sumber data tertulis atau gambar. Sumber tertulis atau gambar berbentuk dokumen resmi, buku, majalah, arsip, dokumen pribadi, dan foto yang terkait dengan permasalahan penelitian (Sudarto, 2002:71). 


\section{PEMBAHASAN DAN HASIL PENELITIAN}

\section{Akta Notaris dalam Batas Kewajaran yang ditentukan Dewan Kehormatan Pusat Ikatan Notaris Indonesia}

Sudah kita ketahui bahwa Akta otentik yang dibuat oleh notaris diatur di dalam KUH Perdata, khususnya Pasal 1867, 1868 dan seterusnya yang merupakan jenis Undangundang di dalam peraturan kita. Selanjutnya akta otentik diatur pula di dalam Undangundang Jabatan Notaris Nomor 30 tahun 2004 jo UU Nomor 2 tahun 2014. Pemberian kualifikasi Notaris sebagai Pejabat Umum berkaitan dengan wewenang Notaris. Menurut Pasal 15 ayat (1) Undang-Undang Jabatan Notaris bahwa Notaris berwenang membuat akta otentik, sepanjang pembuatan akta-akta tersebut tidak ditugaskan atau dikecualikan kepada pejabat atau orang lain (Habib Adjie, 2013: 28).

Dalam penataan kelembagaan (hukum), khususnya untuk Notaris, cukup untuk Notaris dikategorikan sebagai Pejabat Umum saja dan tidak perlu menempelkan atau memberikan sebutan lain kepada Notaris. Notaris sudah pasti Pejabat Umum, tapi Pejabat Umum belum tentu Notaris, karena Pejabat Umum dapat disandang pula oleh Pejabat Pembuat Akta Tanah (PPAT) atau Pejabat Lelang.

Oleh karena itu, bentuk akta otentik ditentukan oleh undang-undang, sedangkan pejabat yang dapat membuatnya tidak dapat dihindarkan agar berbobot yang sama harus pula ditentukan oleh undang-undang (Herlien Budiono, 2010: 59). Tidak semua akta dapat disebut sebagai akta otentik. Sebuah akta disebut akta disebut akta otentik jika memenuhi syarat sebagai berikut ini (Ira dan Yunirman, 2009: 43) :

1. Bentuk akta tidak sesuai yang ditentukan undang-undang. Sebuah akta otentik sudah memiliki bentuk pola sendiri. Jadi seseorang yang ingin membuat akta otentik di hadapan Notaris tidak dapat membuat dengan format sembarangan;

2. Akta otentik dibuat di hadapan pejabat umum yang diangkat negara. Notaris adalah salah satu pejabat umum yang mempunyai wewenang untuk membuat akta otentik;

3. Akta otentik dibuat oleh pejabat yang berwenang atau Notaris yang berhak. Seorang Notaris yang sedang cuti atau sedang bermasalah tidak berhak membuat akta otentik. Seorang notaris yang dibekukan izinnya atau yang belum memiliki izin, tidak berhak membuat akta otentik; 
Sebuah akta autentik merupakan dokumen yang sah dan dapat menjadi alat bukti yang sempurna. Sempurna di sini berarti hakim menganggap semua yang tertera dalam akta merupakan hal yang benar, kecuali ada akta lain yang dapat membuktikan bahwa isi akta pertama tersebut salah. Oleh karena itu, pembuatan sebuah akta autentik menjadi sesuatu yang penting.

Demikian dapat disimpulkan untuk menjamin kepastian tanggal dan waktu salah satu tolak ukur yang menentukan akta tersebut telah sesuai dengan ketentuan UndangUndang Jabatan Notaris adalah pada proses pelaksanaan pembuatan aktanya mulai dari pra pembuatan akta sampai dengan pelaksanaan pembuatan aktanya.

Perhitungan jumlah batas kewajaran pembuatan akta 20 akta perhari ini, jika dijabarkan dengan memperhatikan jam kerja yang lazim digunakan oleh Notaris maka penggunaan waktu tersebut adalah antara pukul 8 (delapan) pagi sampai dengan pukul 17 (tujuh belas) Waktu Indonesia Barat, dan jam istirahat pada pukul 12 (dua belas) sampai dengan pukul 13 (tiga belas) Waktu Indonesia Barat, maka jumlah jam yang dipergunakan adalah 8 (delapan) jam sehari. Artinya apabila tanpa jeda keluar masuk atau berganti orang yang membuat akta, jumlah waktu yang dibutuhkan dengan jumlah pembatasan akta 20 (dua puluh) akta satu hari adalah 8 (delapan) dikali 60 (enam puluh) menit dan dibagi 20 (dua puluh) akta maka didapat hasil 24 (dua puluh empat) menit waktu yang dibutuhkan.

\section{Kecenderungan kwantitas akta Notaris di Kota Padang perharinya}

Berikut ini adalah data yang penulis dapatkan mengenai kwantitas akta notaris setiap bulannya, yang didapatkan dari Majelis Pengawas Daerah Notaris Kota Padang selama 6 bulan pada tahun 2018:

Tabel 1,

Data Majelis Pengawas Daerah Notaris Kota Padang

\begin{tabular}{|l|l|l|l|l|l|l|l|}
\hline $\begin{array}{c}\text { AKTA NOTARIS } \\
\text { KOTA PADANG } \\
\mathbf{2 0 1 8}\end{array}$ & JULI & AGUSTUS & SEPTEMBER & 0KTOBER & NOVEMBER & DESEMBER & T O T A L \\
\hline A & 496 & 468 & 661 & 609 & 589 & 577 & 3.400 \\
\hline B & 115 & 118 & 112 & 141 & 139 & 143 & 768 \\
\hline C & 259 & 252 & 188 & 172 & 213 & 241 & 1.325 \\
\hline D & 163 & 116 & 124 & 109 & 148 & 177 & 837 \\
\hline E & 52 & 59 & 58 & 96 & 65 & 91 & 421 \\
\hline F & 132 & 131 & 121 & 142 & 141 & 160 & 827 \\
\hline
\end{tabular}




\begin{tabular}{|l|l|l|l|l|l|l|l|}
\hline G & 65 & 57 & 50 & 39 & 71 & 27 & 309 \\
\hline H & 138 & 153 & 123 & 138 & 141 & 141 & 834 \\
\hline I & 142 & 198 & 178 & 231 & 221 & 223 & 1.193 \\
\hline J & 362 & 252 & 309 & 284 & 247 & 264 & 1.718 \\
\hline
\end{tabular}

Sumber: Majelis Pengawas Daerah Notaris Kota Padang

Dari table tersebut diatas, ada 10 (sepuluh) subjek Notaris yang menjadi sampel pada Tesis ini. Dapat diperhatikan jumlah akta yang telah dibuat oleh Notaris dari bulan Juli hingga Desember tahun 2018 di Kota Padang, yang mana apabila dikalkulasikan yaitu jumlah akta perbulan dibagi dengan jumlah hari pada masa jam kerja selama 1 (satu) bulan yakni masa kerja efektif dari hari senin sampai hari jumat sehingga selama 1 (satu) bulan efektifitas kerja adalah sebanyak 20 (dua puluh) hari dengan tersebut sehingga didapat data perkiraan sebagai berikut:

1. Notaris A membuat sebanyak 25 akta notaris perharinya;

2. Notaris B membuat sebanyak 6 akta notaris perharinya;

3. Notaris $\mathrm{C}$ membuat sebanyak 11 akta notaris perharinya;

4. Notaris D membuat sebanyak 6 akta notaris perharinya;

5. Notaris E membuat sebanyak 3 akta notaris perharinya;

6. Notaris F membuat sebanyak 6 akta notaris perharinya;

7. Notaris $\mathrm{G}$ membuat sebanyak 3 akta notaris perharinya;

8. Notaris $\mathrm{H}$ membuat sebanyak 6 akta notaris perharinya;

9. Notaris I membuat sebanyak 10 akta notaris perharinya;

10. Notaris J membuat sebanyak 12 akta notaris perharinya.

Dengan ini dapat disimpulkan bahwa kecenderungan kwantitas akta yang dibuat notaris di Kota Padang masih dalam batas wajar yang ditentukan oleh DKP.INI. Sesuai Pasal 13 ayat 1 Anggaran Dasar Perkumpulan menentukan bahwa untuk menjaga kehormatan dan keluhuran martabat jabatan Notaris tersebut Perkumpulan mempunyai Kode Etik Notaris yang ditetapkan oleh Kongres dan merupakan kaidah moral yang wajib ditaati oleh setiap anggota Perkumpulan. Keputusan kongres adalah merupakan kesepakatan bersama para anggota perkumpulan yang sah. Apa yang telah disepakati di dalam Kongres wajib dipatuhi oleh semua anggota perkumpulan. Salah satu yang telah disepakati di dalam Kongres Ikatan Notaris Indonesia adalah mengenai batas kewajaran pembuatan akta.

Sesuai ketentuan Pasal 9 ayat 1 UUJN, pelanggaran terhadap Kode Etik Notaris dapat dikenakan sanksi berupa pemberhentian sementara dari jabatannya. Oleh karenanya 
pelanggaran terhadap ketentuan batas kewajaran pembuatan merupakan pelanggaran terhadap larangan yang diatur dalam Kode Etik Notaris, maka atas pelanggaran tersebut juga dapat dikenakan sanksi sesuai ketentuan UUJN sebagaimana ditetapkan di dalam Pasal 9 ayat 1 UUJN.

Secara norma, pengawasan penegakan kode etik Notaris khususnya di Kota Padang dilakukan secara berjenjang yakni dimulai dari tingkat daerah, tingkat wilayah dan di tingkat pusat. Dengan tujuan untuk efisiensi dan efektifitas pengawasan itu sendiri, jadi tidak akan tertumpuk hanya di suatu kawasan tertentu saja. Dewan Kehormatan Daerah adalah unsur pelaksana pengawasan dan pembinaan penting yang berinteraksi langsung dengan notaris dan pihak yang mengetahui duduk perkara pelanggaran kode etik pertama kalinya. Disinilah tugas berat dewan kehormatan daerah yang harus mengemban fungsi check and balance pertama kali terhadap sebuah kasus dugaan pelanggaran kode etik. Oleh karena itu, dalam tataran ideal, dewan kehormatan daerah harusnya menjadi institusi yang pertama kali mengetahui adanya dugaan pelanggaran kode etik yang dilakukan oknum notaris tertentu. Akan tetapi menurut teori perundang-undangan, DKP.INI seharusnya tidak bisa membatasi kwantitas akta yang dibuat notaris setiap harinya. Dengan adanya peraturan tersebut, DKP.INI sendiri telah melangkahi Undang-Undang Jabatan Notaris, yaitu peraturan yang lebih tinggi diatasnya. Peraturan seperti ini seharusnya dikeluarkan oleh pemerintah dan bukan oleh suatu organ dari sebuah perkumpulan.

\section{Akibat hukum terhadap akta yang melebihi batas kewajaran}

Dalam hal penegakkan kode etik Pasal 4 ayat 16 Kode Etik Notaris, sesuai data yang didapatkan dari Majelis Pengawas Daerah Notaris Kota Padang, sampai data terakhir di tahun 2019, masih terdapat Notaris yang melanggar ketentuan Per.DKP.INI 1/2017. Tentunya ketegasan dalam mengambil sikap dan keputusan ini dilandasi oleh pemahaman yang jelas pula bahwa pengawasan dimaksud haruslah meliputi fungsi pembinaan dan perlindungan.

Mencermati dari sisi pengawasan pemberian sanksi terhadap penegakan peraturan Dewan Kehormatan Pusat Ikatan Notaris Indonesia Nomor 1 Tahun 2017 yang dilakukan oleh Notaris sebenarnya apabila mengacu pada angka 8 jelas sangat tegas sebab sanksi yang diberikan merupakan sanksi yang dapat memberhentikan Notaris dengan usulan 
pemecatan kepada Menteri Hukum dan Hak Asasi Manusia Republik Indonesia, akan tetapi dalam proses pengawasan penegakan sanksi tersebut tentu harus didahului dengan pemeriksaan kemudian dari pemeriksaan itu barulah dapat ditemukan adanya pelanggaran atau tidak sehingga sanksi tersebut dapat diterapkan.

Akan tetapi, akta yang telah dibuat melebihi batas wajar yang ditentukan oleh dewan kehormatan tidaklah semerta-merta menjadi batal, karena jika dalam pembuatan akta tersebut tidak menyalahi UUJN. Berikut ini beberapa hal yang membuat batal/terdegradasinya suatu akta:

1. Akta Tidak Dibacakan

Notaris juga dihadapkan pada persoalan untuk menciptakan hukum dalam menyelesaikan masalah yang mungkin muncul atau telah ada diantara para pihak, sehingga diperoleh penyelesaian yang memuaskan bagi para pihak. Dalam mengemban tugas demikian, maka dibutuhkan kemampuan prefesionalisme dalam merumuskan keinginan dari para pihak dan tetap menjaga posisinya senetral mungkin dari kemungkinan keberpihakan terhadap kepentingan dari salah satu penghadap.

2. Adanya Unsur Pemaksaan Untuk Menandatangani Akta

Substansi akta notaris merupakan formulasi atas pernyataan dari keinginan para penghadap yang dikemukakan dihadapan notaris. Notaris tidak dapat memaksakan keinginan atau pendapatnya agar diikuti oleh para penghadap, tapi notaris wajib memberikan penjelasan dari segi hukum. Jika saran notaris disetujui oleh para penghadap kemudian dituangkan dalam bentuk akta, maka hal tersebut merupakan keinginan para penghadap sendiri, bukan keinginan atau keterangan notaris. Berdasarkan pada substansi akta tersebut, maka ada akta notaris yang deklaratif dan akta notaris yang konstitutif (Habib Adjie, 2007: 142).

Apabila penghadap tidak dapat atau berhalangan membubuhkan tanda tangannya diatas akta, maka keterangan tentang alasan tidak dapat atau berhalangan tersebut dinyatakan secara tegas oleh notaris dalam akta. Sedangkan apabila penghadap tidak dapat membubuhkan tanda tangannya karena tidak dapat membaca atau menulis maka penghadap yang bersangkutan dapat memberikan cap jempolnya. Cap jempol bukan merupakan tanda tangan melainkan suatu tanda. Pemberian cap jempol itu harus dinyatakan pula dalam akta. 
3. Adanya Syarat Formil yang tidak Terpenuhi

Dalam suatu pengikatan jual beli, para pihak dapat menerapkan suatu janji dengan memakai denda, gunanya adalah sebagai peringatan atau pengawasan bagi pihak-pihak untuk memenuhi janjinya sesuai dengan apa yang tercantum didalam akta tersebut. Kebatalan menyangkut persoalan tidak terpenuhinya syarat sahnya suatu perjanjian sebagaimana disebutkan diatas diklasifikasikan sebagai dua kategori, yaitu syarat subjektif dan syarat objektif. Syarat subjektif meliputi adanya kesepakatan mereka yang mengikatkan dirinya dan kecakapan untuk membuat suatu perjanjian. Sedangkan syarat objektif meliputi adanya suatu hal tertentu dan sebab yang diperbolehkan.

Tidak terpenuhinya syarat subjektif mengakibatkan suatu perjanjian dapat dibatalkan atau dapat dimintakan pembatalan oleh salah satu pihak, sedangkan tidak terpenuhinya syarat objektif menyebabkan suatu perjanjian batal demi hukum secara serta merta atau perjanjian dianggap tidak pernah ada dan tujuan para pihak yang mengadakan perjanjian tersebut untuk melahirkan suatu perikatan hukum telah gagal. Dengan demikian, tidak ada dasar bagi para pihak untuk saling menuntut di depan hakim. Batal demi hukum selain karena tidak terpenuhinya unsur objektif, juga undang-undang merumuskan secara konkrit tiap-tiap perbuatan hukum terutama perjanjian yang bersifat formil mensyaratkan dibentuknya perjanjian dalam bentuk yang ditentukan oleh undang-undang, dan jika tidak dipenuhi maka perjanjian tersebut batal demi hukum atau tidak memiliki kekuatan pembuktian. Pembatalan akta sesuai dalam pasal 1266 Kitab Undang-undang Hukum Perdata dapat disimpulkan bahwa ada tiga hal yang harus diperhatikan sebagai syarat pembatalan suatu perjanjian, yaitu perjanjian harus bersifat timbal balik, pembatalan harus dilakukan dihadapan hakim dan harus ada wanprestasi. Perjanjian dapat dimintakan pembatalannya kepada hakim dengan dua cara, yaitu dengan cara aktif, yaitu menuntut pembatalan perjanjian di depan hakim dan dengan cara pembelaan, yaitu menunggu sampai digugat di depan hakim untuk memenuhi perjanjian dan baru mengajukan alasan mengenai kekurangan perjanjian itu (Subekti, 1985: 23). 


\section{PENUTUP}

1. Notaris diberikan batasan wajar tentang akta yang bisa mereka buat perharinya agar Notaris tidak melebihi batas kemampuan mereka secara lahiriah dalam membuat akta perhari. Ditinjau dari waktu yang digunakan untuk merumuskan suatu akta bagi para pihak akan memakan banyak waktu, sehingga dapat mengakomodasi keinginan para pihak dengan lebih maksimal.

2. Kecenderungan kwantitas akta notaris di Kota Padang masih dalam batas kewajaran yang ditentukan peraturan DKP.INI, sehingga penerapan kode etik dalam peraturan DKP.INI Nomor 1 Tahun 2017 sudah berjalan sesuai dengan yang diharapkan.

3. Undang-Undang Jabatan Notaris tidak membatasi jumlah akta yang bisa dibuat oleh Notaris perharinya. Sesuai Undang-Undang Jabatan Notaris Pasal 38, Notaris menjamin kepastian waktu dan tanggal pembuatan akta dan hal itu menjadi tolak ukur yang menentukan bahwa akta itu sesuai dengan ketentuan Undang-Undang Jabatan Notaris. Akta Notaris yang melebihi batas kewajaran yang ditentukan Dewan Kehormatan Notaris tidak akan terdegradasi menjadi akta dibawah tangan, asalkan yang dilakukan Notaris tersebut dalam pembuatan aktanya sesuai dengan UndangUndang Jabatan Notaris.

\section{DAFTAR PUSTAKA}

Penulisan naskah dan sitasi yang diacu dalam naskah ini disarankan menggunakan aplikasi referensi (reference manager) seperti Mendeley, Zotero, Reffwork, Endnote dan lain-lain. Artikel wajib merujuk 5-15 jurnal dan dua artikel pada Jurnal Cendekia Hukum [Times New Roman, 12, normal], spasi 1. (rujuk pada pedoman penulisan). 